\title{
Short- and Long-Term Effects of Lime and Gypsum Applications on Acid Soils in a Water-Limited Environment: 2. Soil Chemical Properties
}

\author{
Geoffrey C. Anderson ${ }^{1, *} *$, Shahab Pathan ${ }^{2} \oplus$, James Easton ${ }^{3}$, David J. M. Hall ${ }^{4}$ and \\ Rajesh Sharma ${ }^{5}$ (D) \\ 1 Department of Primary Industries and Regional Development, Northam 6401, Australia \\ 2 Department of Primary Industries and Regional Development, South Perth 6151, Australia; \\ shahab.pathan@dpird.wa.gov.au \\ 3 CSBP Limited, Kwinana 6966, Australia; James.Easton@csbp.com.au \\ 4 Department of Primary Industries and Regional Development, Esperance 6450, Australia; \\ david.hall@dpird.wa.gov.au \\ 5 ChemCentre, Resources and Chemistry Precinct Level 2, Bentley 6102, Australia; \\ RSharma@chemcentre.wa.gov.au \\ * Correspondence: geoff.anderson@dpird.wa.gov.au
}

Received: 5 November 2020; Accepted: 10 December 2020; Published: 17 December 2020

check for updates

\begin{abstract}
Soil acidity or aluminum (Al) toxicity is a major limitation to crop production. In this paper, we examine the effects of surface-applied lime and gypsum on soil profile chemical properties that affect $\mathrm{Al}$ toxicity in short-term (1 year), medium-term (2 years and 8 months) and long-term (10 years) experiments. Sulfate applied to the soil surface as gypsum was leached rapidly to a depth of $40 \mathrm{~cm}$ in the short-term despite relatively low amounts $(279 \mathrm{~mm})$ of rainfall. In the medium and long-term experiments, $28-54 \%$ of the sulfate applied as gypsum was retained in the $0-50 \mathrm{~cm}$ soil layer due to adsorption and precipitation reactions. The combined application of lime and gypsum increased soil calcium, to a depth of $30 \mathrm{~cm}$ in the short-term and to a depth of $50 \mathrm{~cm}$ in the medium and long-terms. Increases in soil sulfate and calcium were associated with greater electrical conductivity to a depth of $50 \mathrm{~cm}$ for all sampling times. Application of lime alone had no impact on soil $\mathrm{Al}, \mathrm{pH}$, and calcium in the soil layers below $10 \mathrm{~cm}$ in the short and medium terms. In the long-term, increasing the rate of lime application from 2 to $8 \mathrm{t} \mathrm{L} \mathrm{ha}^{-1}$ increased soil $\mathrm{pH}$ in the $10-20 \mathrm{~cm}$ soil layer while soil Al decreased to a depth of $30 \mathrm{~cm}$. The combined use of lime and gypsum decreased soil Al in the $30-50 \mathrm{~cm}$ soil layer in the medium-term and the $20-30 \mathrm{~cm}$ soil layer in the long-term which was more than when only lime was applied. Hence, we recommend the use of lime plus gypsum for treating soils with subsoil Al toxicity. Additionally, soil Al measurements are a more sensitive measurement of the impact of surface application lime and lime plus gypsum than soil $\mathrm{pH}$.
\end{abstract}

Keywords: aluminum toxicity; calcium; electrical conductivity; pH; soil acidity; sulfate

\section{Introduction}

Aluminum ( $\mathrm{Al})$ present in the soil solution as $\mathrm{Al}\left(\mathrm{H}_{2} \mathrm{O}\right)_{6}^{3+}$ abbreviated, as $\mathrm{Al}^{3+}$, is toxic to root growth [1]. Soil $\mathrm{pH}_{\mathrm{CaCl}_{2}}$ and soil $\mathrm{Al}_{\mathrm{CaCl}_{2}}$ ( $\mathrm{Al}$ and $\mathrm{pH}$ measured using $0.01 \mathrm{MCaCl}_{2}$ ) are used to indicate the potential limitations imposed by soil acidity and $\mathrm{Al}$ toxicity, respectively [2]. When the subsoil or soil layers below $10 \mathrm{~cm}$ contain an $\mathrm{Al}_{\mathrm{CaCl}_{2}}$ content greater than $2.5 \mathrm{mg} \mathrm{Al} \mathrm{kg}{ }^{-1}$, there is a significant reduction in wheat (Triticum aestivum L.) grain yield. Lime $\left(\mathrm{L}, \mathrm{CaCO}_{3}\right)$ applied to $\mathrm{Al}$ toxic soils increases soil $\mathrm{pH}_{\mathrm{CaCl}_{2}}$ and decreases soil $\mathrm{Al}_{\mathrm{CaCl}_{2}}$ resulting in increased crop grain yields [2,3]. However, due to its comparatively low solubility, L broadcast onto the soil surface can be ineffective at treating subsoil 
$\mathrm{Al}$ toxicity in the short-term and medium-term [2]. Alternatively, gypsum $\left(\mathrm{G}, \mathrm{CaSO}_{4} \cdot 2 \mathrm{H}_{2} \mathrm{O}\right)$ has the potential to be more effective in treating subsoil $\mathrm{Al}$ toxicity due to its greater solubility $\left(2.1 \mathrm{gm} \mathrm{L}^{-1}\right.$ in water) compared to $\mathrm{L}$ which is sparingly soluble in water $\left(0.013 \mathrm{gm} \mathrm{L}^{-1}\right)[4,5]$. The application of $\mathrm{G}$ increases the sulfate $\left(\mathrm{SO}_{4}-\mathrm{S}\right)$ and calcium $(\mathrm{Ca})$ concentration of the soil solution leading to an increase in soil solution electrical conductivity (EC) [5]. Higher soil solution EC decreases the activity of $\mathrm{Al}^{3+}$ in the soil solution meaning plants can tolerate greater levels of $\mathrm{Al}^{3+}$ toxicity [4]. Additionally, the increase in soil $\mathrm{SO}_{4}-\mathrm{S}$ content results in the conversion of toxic $\mathrm{Al}^{3+}$ to $\mathrm{Al}$ sulfate $\left(\mathrm{Al}^{-} \mathrm{SO}_{4}\right)$, which is not harmful to plant roots [6-8].

The application of $\mathrm{G}$ can either decrease, increase or have no effect on soil $\mathrm{pH}_{\mathrm{CaCl}_{2}}$ [9]. A decrease in soil $\mathrm{pH}_{\mathrm{CaCl}_{2}}$ arises when added Ca displaces $\mathrm{Al}^{3+}$ and hydrogen ions $\left(\mathrm{H}^{+}\right)$from the cation exchange sites into the soil solution [10]. By contrast, an increase in $\mathrm{pH}_{\mathrm{CaCl}_{2}}$ happens due to $\mathrm{SO}_{4}-\mathrm{S}$ sorption resulting in the displacement of hydroxide ions $\left(\mathrm{OH}^{-}\right)$[11]. The net effect of these two reactions will determine the overall impact on $\mathrm{pH}_{\mathrm{CaCl}_{2}}$ [9]. For soils with high $\mathrm{SO}_{4}$-S sorption capacities, the net effect is to increase soil $\mathrm{pH}_{\mathrm{CaCl}_{2}}$ [12]. In contrast, for soils with low $\mathrm{SO}_{4}-\mathrm{S}$ sorption capacities, the net result is to decrease $\mathrm{pH}_{\mathrm{CaCl}_{2}}$. The $\mathrm{SO}_{4}-\mathrm{S}$ sorption capacity can be measured using the sulfur buffer index (SBI) [13]. Brazilian studies have shown that soils that have high $\mathrm{SO}_{4}-\mathrm{S}$ sorption capacity have a greater $\mathrm{G}$ requirement to overcome the $\mathrm{Al}$ toxicity limitations [14]. In contrast, $\mathrm{G}$ application did not affect the soil solution $\mathrm{pH}$ of soils of South Western Australia [6] because these soils generally have a low SBI [13].

Leaching of $\mathrm{SO}_{4}-\mathrm{S}$ from the $0-20 \mathrm{~cm}$ soil layer occurs in the medium rainfall zone of South Western Australia [15]. However, retention of this leached $\mathrm{SO}_{4}-\mathrm{S}$ takes place in the soil layers below $20 \mathrm{~cm}$ due to the greater $\mathrm{SO}_{4}-\mathrm{S}$ adsorption properties [15]. In general, soil layers below $10 \mathrm{~cm}$ have a greater capacity to adsorb $\mathrm{SO}_{4}-\mathrm{S}$ due to the lower carbon, phosphorus, $\mathrm{pH}$, and greater clay content [13]. The rate of $\mathrm{SO}_{4}-\mathrm{S}$ leaching is related to the water holding capacity of the soil, the amount and frequency of rainfall events, and the $\mathrm{SO}_{4}$-S adsorption properties [15]. Hence, the rate of $\mathrm{SO}_{4}-\mathrm{S}$ leaching will be less in the low rainfall zone of South Western Australia compared to the rates observed in the medium rainfall zone [15]. Additionally, some soils within the region have net anion exchange capacity, which can reduce the rate of nitrate leaching [16]. The reduction in $\mathrm{SO}_{4}-\mathrm{S}$ leaching in soil with anion exchange capacity is expected to be greater than that which occurs for nitrate because soils adsorb $\mathrm{SO}_{4}-\mathrm{S}$ more strongly than nitrate. Calcium (Ca), when applied as $\mathrm{G}$ and L, can also be leached into the soil profile. The rate of leaching of $\mathrm{G}$ and $\mathrm{L}$ derived $\mathrm{Ca}$ varies according to the rates applied, reaction time and the soil type [17]. Calcium derived from $\mathrm{G}$ is leached at a faster rate than Ca derived from $\mathrm{L}$ because of the greater solubility of $\mathrm{G}$ compared to $\mathrm{L}$ and due to the presence of $\mathrm{SO}_{4}-\mathrm{S}$ as co-anions of $\mathrm{G}[17,18]$. Additionally, $\mathrm{L}$ application increases soil $\mathrm{pH}$ and the effective cation exchange capacity (ECEC), which reduces the mobility of $\mathrm{Ca}$ due to the increased attraction by the $\mathrm{pH}$-dependent negative charges of the soil particles [17].

In the first paper of this series, we concluded that the application of $G$ is profitable in the low-rainfall, eastern wheat belt region of Western Australia despite the soils having a low capacity to adsorb $\mathrm{SO}_{4}-\mathrm{S}$ which results in rapid leaching of $\mathrm{SO}_{4}-\mathrm{S}$ and no self-liming effect [3]. In this paper, we examine the impact of surface application of $G$ and $L$ on soil chemical properties overtime to explain these crop grain yield responses. In this paper, we present changes in soil profile $\mathrm{SO}_{4}-\mathrm{S}, \mathrm{Ca}$, $\mathrm{EC}, \mathrm{Al}, \mathrm{pH}$ and ECEC over time. We hypothesize that measurement of soil $\mathrm{Al}$, as opposed to $\mathrm{pH}$, will provide a more sensitive measurement of the impact of surface-applied $\mathrm{L}$ on subsoil chemical properties. Additionally, the combined application of L and $\mathrm{G}$ will result in a greater reduction in soil Al than when L is applied alone. 


\section{Materials and Methods}

\subsection{Field Experimental Sites}

The short-term (ST, 1 year), and medium-term (MT, 2 years and 8 months) experiments were located near the town of Burracoppin ( $-31^{\circ} 30^{\prime} 9^{\prime \prime} \mathrm{S}$ latitude, $118^{\circ} 38^{\prime} 50^{\prime \prime}$ E longitude) and had a total of 2-4 $\mathrm{t} \mathrm{L} \mathrm{ha}{ }^{-1}$ applied in the previous 15 years before the commencement of the experiment. The third was a long-term (LT, 10 years) experiment located near the town of Bonnie Rock ( $-30^{\circ} 37^{\prime} 3^{\prime \prime}$ S latitude, $118^{\circ} 14^{\prime} 9^{\prime \prime}$ E longitude) and had no history of $\mathrm{L}$ application. The experiments are located in the low rainfall region of the South Western Australian grain belt. Long term (1980-2018) average rainfall for the Bonnie Rock and Burracoppin sites are $309 \mathrm{~mm}$ (range 158-453 mm) and $364 \mathrm{~mm}$ (range $315-414 \mathrm{~mm}$ ) respectively. While Bonnie Rock and Burracoppin are in the same rainfall zone, rainfall amount and distribution can differ, for example, annual rainfall at Bonnie Rock was $296 \mathrm{~mm}$ compared Burracoppin of $400 \mathrm{~mm}$ in 2015 [3]. Crop grain yield and nutrient concentration and measured soil chemical properties from the control treatment are presented by [3]. In summary, G application was profitable at the MT experiment where deep ripping had removed the subsoil compaction constraint. In contrast, the most profitable treatment at the LT experiment was where L and G were applied together. The soils at the experimental sites are classified as Tenosols [19]. At the LT site, the gravel content increased from $5 \%$ in $0-10 \mathrm{~cm}$ to $56 \%$ in $30-50 \mathrm{~cm}$, which reduces the water holding capacity.

In the ST experiment, we top-dressed the $G$ and L treatments on 31 March 2017. The treatments consisted of: a control (C), $2.5 \mathrm{t} \mathrm{L} \mathrm{ha}^{-1}$ (L2.5), $2.5 \mathrm{t}_{\text {gypsum ha }}{ }^{-1}$ (G2.5) and, $2.5 \mathrm{t} \mathrm{L} \mathrm{ha}{ }^{-1}$ plus $2.5 \mathrm{t}$ gypsum ha ${ }^{-1}(\mathrm{~L} 2.5+\mathrm{G} 2.5)$. The MT experiment consisted of the same $\mathrm{L}$ and $\mathrm{G}$ treatments as the ST experiment, plus additional treatments comprising $5.0 \mathrm{t} \mathrm{L} \mathrm{ha}^{-1}$ (L5.0) and $5.0 \mathrm{t} \mathrm{L} \mathrm{ha}^{-1}$ plus $2.5 \mathrm{t} \mathrm{G}$ $\mathrm{ha}^{-1}$ (L5.0 + G2.5). In this experiment, we broadcasted the L and G treatments on 31 July 2015, which was followed by deep ripping and cultivation. The LT experiment treatments consisted of: a control (C) $2.0 \mathrm{t} \mathrm{L} \mathrm{ha}^{-1}$ (L2), $4.0 \mathrm{t} \mathrm{L} \mathrm{ha}^{-1}$ (L4), $8.0 \mathrm{t} \mathrm{L} \mathrm{ha}^{-1}$ (L8), $2.0 \mathrm{t} \mathrm{G} \mathrm{ha}^{-1}$ (G2), and $4.0 \mathrm{t} \mathrm{L} \mathrm{ha}^{-1}$ plus $2.0 \mathrm{t} \mathrm{G} \mathrm{ha}{ }^{-1}$ (L4 + G2). We broadcasted half $\left(1,2\right.$, and $4 \mathrm{t} \mathrm{L} \mathrm{ha}^{-1}$, and $\left.1 \mathrm{t} \mathrm{G} \mathrm{ha}{ }^{-1}\right)$ of the $\mathrm{L}$ and $\mathrm{G}$ rates in March of 2008 and in March of 2013. We used three treatments replication in all experiments. The distance of the experiment site for $\mathrm{L}$ sources was $370-380 \mathrm{~km}$ compared for the G source of $140-200 \mathrm{~km}$. The L source consisted of $80-93 \% \mathrm{CaCO}_{3}$ while the $\mathrm{G}$ source contained $175-178 \mathrm{~g} \mathrm{~S} \mathrm{~kg}^{-1}$ and 214-224 $\mathrm{g} \mathrm{Ca} \mathrm{kg}^{-1}$ [3].

Crops grown at the MT experiments were canola (Brassica napus L. cv Bonito) in 2016, wheat (cv Calingiri) in 2017, and barley (Hordeum vulgare cv Spartacus CL) in 2018. The same crops were grown at the ST experiment in 2017 and 2018. Wheat was grown at the LT experiment in 2008, 2010, 2011, 2013, 2014, 2015, and 2016. Seeding occurred with farmer equipment for the ST and MT experimental sites and plot cone seeder for the LT site in May. We used a small plot header to harvest the plots in November of each year.

\subsection{Soil Measurements}

We collected four $5 \mathrm{~cm}$ diameter soil cores in depth increments of $10 \mathrm{~cm}$ to $50 \mathrm{~cm}$ from each plot in March 2018 which was 1 year (ST), 2 years and 8 months (MT), and 10 years (LT) after the application of $\mathrm{L}$ and $\mathrm{G}$ treatments. The four cores were bulked to provide soil profile samples for each plot. In this paper, treatment effects on $\mathrm{pH}_{\mathrm{CaCl}_{2}}$ and $\mathrm{Al}_{\mathrm{CaCl}_{2}}$ were measured using a 1:5 soil to $0.01 \mathrm{M} \mathrm{CaCl}_{2}$ solution extraction and electrical conductivity (EC) using the same soil to solution ratio but with water [20]. The extractable sulfur content of the soil profile was measured using $0.25 \mathrm{M} \mathrm{KCl}$ heated for $3 \mathrm{~h}$ at $40{ }^{\circ} \mathrm{C}\left(\mathrm{S}_{\mathrm{KCl} 140}\right)$ [21]. Soil buffer index (SBI) was measured to assess the $\mathrm{S}_{-} \mathrm{SO}_{4}$ adsorption properties of the soil using the procedure of [13] in the control treatments [3]. Exchangeable cations, $\mathrm{Al}\left(\mathrm{Al}_{\mathrm{Ex}}\right), \mathrm{Ca}$ $(\mathrm{Ca} \mathrm{Ex})$, potassium $\left(\mathrm{K}_{\mathrm{Ex}}\right)$, magnesium $\left(\mathrm{Mg}_{\mathrm{Ex}}\right)$ and sodium $\left(\mathrm{Na}_{\mathrm{Ex}}\right)$, were extracted using an unbuffered solution of $0.1 \mathrm{M}$ ammonium chloride and barium chloride at 1:10 soil to solution ratio with cation concentration measured by ICP-AES [20]. The ECEC value is calculated as the sum of the cations, $\mathrm{Al}_{\mathrm{Ex}}$, $\mathrm{Ca}_{\mathrm{Ex}}, \mathrm{K}_{\mathrm{Ex}}, \mathrm{Mg}_{\mathrm{Ex}}$ and $\mathrm{Na}_{\mathrm{Ex}}$ [20]. The percentage of cation occupied by $\mathrm{Al}_{\mathrm{Ex}} \%$ and $\mathrm{Ca}_{\mathrm{Ex}} \%$ is $\mathrm{Al}_{\mathrm{Ex}}$ or $\mathrm{Ca}_{\mathrm{Ex}}$ divided by ECEC multiplied by 100 . Other soil nutrient measurements included ammonium 
and nitrate, Colwell phosphorus and potassium, phosphorus buffering index, organic carbon, DTPA extractable copper, manganese, and zinc, and hot boron are summarized by [3].

\subsection{Lime and Gypsum Recovery}

Calculated $\mathrm{SO}_{4}-\mathrm{S}$ and Ca recovered from applied $\mathrm{G}$ is the difference between $\mathrm{S}_{\mathrm{KCl} 40}\left(\mathrm{mg} \mathrm{S} \mathrm{kg}^{-1}\right)$ and $\mathrm{Ca}_{\mathrm{Ex}}\left(\mathrm{mg} \mathrm{Ca} \mathrm{kg}^{-1}\right)$ content of each soil layer between the $\mathrm{G}$ and the $\mathrm{C}$ treatment. In the calculation, we used a bulk density of $1.7 \mathrm{gm} \mathrm{cm}^{3}$ multiplied by the sampling depth $(10 \mathrm{~cm})$ to convert $\mathrm{mg} \mathrm{kg}^{-1}$ to $\mathrm{kg} \mathrm{ha}^{-1}$. The difference for each soil layer is then summed to give the amount of $G$ or $L$ recovered in the $0-50 \mathrm{~cm}$ soil layer of the three experimental sites [3]. Percent $L$ or $G$ recovered in then the summed amount divided by the amount applied. In doing the calculation, we used the measured $\mathrm{Ca}$ and $\mathrm{S}$ content of the $\mathrm{G}$ and the $\mathrm{CaCO}_{3}$ content of the $\mathrm{L}$ sources. Gravel content for the LT experiment, reduced $\mathrm{S}_{\mathrm{KCl} 40}$ and $\mathrm{Ca}_{\mathrm{Ex}}$ content when expressed in the units of $\mathrm{kg} \mathrm{ha}^{-1}$.

\subsection{Statistical Analysis}

For individual soil layers, analysis of variance was done using a treatment structure of treatments and a block structure of replicates to determine the significance of amendment treatment main effects at each soil depth using Genstat ${ }^{\circledR}[22]$. Differences between treatments were then determined using the Duncan multiple range test. Throughout the paper, the least significant difference values, were determined at $p \leq 0.05$. The exception where $p \leq 0.07$ was used to denote significance because of the high variability in some measurements. These exceptions were, in the ST experiment for calculated $\mathrm{SO}_{4}$-S recovery from the applied $\mathrm{G}$ (Table 1), in the MT experiment for $\mathrm{Al}_{\mathrm{CaCl}_{2}}, \mathrm{Al}_{\mathrm{Ex}}$ and the LT experiment for $\mathrm{pH}_{\mathrm{CaCl}_{2}}$. In retrospect, to account for the high variability, we should have collected more than four soil profile cores per plot. Regression equations for comparison between soil measurements were determined using the regression SigmaPlot ${ }^{\circledR} 12.5$ analysis regression wizard [23].

Table 1. Recovery (\%) of the applied $\mathrm{SO}_{4}$-S as calculated by the difference in $\mathrm{S}_{\mathrm{KCl}_{40}}$ between the $\mathrm{G}$ and $\mathrm{C}$ treatments for the short-term (ST), medium-term (MT) and long-term (LT) experiments using soil samples collected in March 2018.

\begin{tabular}{|c|c|c|c|c|c|c|c|}
\hline \multirow[b]{2}{*}{ Depth (cm) } & \multirow{2}{*}{$\begin{array}{c}\text { ST } \\
\text { G2.5 }\end{array}$} & \multicolumn{3}{|c|}{ MT } & \multicolumn{3}{|c|}{ LT } \\
\hline & & $\mathrm{L} 2.5+\mathrm{G} 2.5$ & G2.5 & $\mathrm{L} 2.5$ + G2.5 & L5.0 + G2.5 & G2.0 & $\mathrm{L} 4+\mathrm{G} 2$ \\
\hline $0-10$ & NA & NA & 10 & 13 & 29 & 30 & 6 \\
\hline $10-20$ & 34 & 41 & 9 & 10 & 23 & 9 & 6 \\
\hline $20-30$ & 17 & 18 & 4 & 6 & 11 & 7 & 8 \\
\hline $30-40$ & 7 & 9 & 2 & 7 & 12 & 6 & 7 \\
\hline $40-50$ & 1 & 2 & 3 & 8 & 8 & 3 & 5 \\
\hline Total & NA & NA & 28 & 31 & 54 & 26 & 27 \\
\hline
\end{tabular}

$\mathrm{L}$ is the lime treatments. NA Recoveries are greater than $100 \%$ due to the insufficient number of soil cores collected to account for site variation.

\section{Results}

\subsection{Sulphur}

Soil $\mathrm{S}_{\mathrm{KCl} 40}$ in the ST experiment for the $\mathrm{C}$ treatment increased from $14-22 \mathrm{mg} \mathrm{S} \mathrm{kg}^{-1}$ in the $0-10 \mathrm{~cm}$ to $28-61 \mathrm{mg} \mathrm{S} \mathrm{kg}^{-1}$ in the $40-50 \mathrm{~cm}$ soil layer (Figure 1a). In the ST experiment, G application increased soil $\mathrm{S}_{\mathrm{KCl} 140}$, from 22 to $537-676 \mathrm{mg} \mathrm{S} \mathrm{kg}^{-1}$ in the $0-10 \mathrm{~cm}$ soil layer which was equivalent to more than the amount of $\mathrm{SO}_{4}-\mathrm{S}$ applied (Table 1). In contrast, the application of $\mathrm{L}$ had no effect on soil $\mathrm{S}_{\mathrm{KCl}}$ in the ST. In the MT, the L5.0 + G2.5 treatment increased soil $\mathrm{S}_{\mathrm{KCl} 40}$ by $526-551 \%$ in the $0-20 \mathrm{~cm}$ soil layer and by $53-157 \%$ in the $20-50 \mathrm{~cm}$ soil layer compared to the $C$ treatment (Figure $1 \mathrm{~b}$ ). In the MT, these increases accounted for $28-54 \%$ of the applied $\mathrm{SO}_{4}-\mathrm{S}$ (Table 1). In the LT, G alone increased $\mathrm{S}_{\mathrm{KCl} 40}$ by $415 \%$ in the $0-10 \mathrm{~cm}$ soil layer (Figure 1c), while $S_{\mathrm{KCl}}$ ( was $56-144 \%$ greater for the $\mathrm{G}$ treatments 
compared to the $\mathrm{C}$ treatment in the $10-50 \mathrm{~cm}$ soil layers. In the $\mathrm{LT}$, these increases in $\mathrm{S}_{\mathrm{KCl} 40}$ only accounted for $26-27 \%$ of applied $\mathrm{SO}_{4}-\mathrm{S}$ (Table 1 ).

\subsection{Calcium}

Soil $\mathrm{Ca}_{\mathrm{Ex}}$ decreased from $1.96-3.23 \mathrm{cmol} \mathrm{kg}^{-1}$ in the $0-10 \mathrm{~cm}$ to $0.23-0.35 \mathrm{cmol} \mathrm{kg}^{-1}$ in the $40-50 \mathrm{~cm}$ soil layer for the ST and MT experiments (Figure 1d,e). Soil $\mathrm{Ca}_{\mathrm{Ex}}$ was lower for the LT experiment, but the content also decreased with increasing soil depth from $0.81 \mathrm{cmol} \mathrm{kg}^{-1}$ in the $0-10 \mathrm{~cm}$ to $0.49 \mathrm{cmol} \mathrm{kg}^{-1}$ in the $40-50 \mathrm{~cm}$ soil layer (Figure 1f).

In the ST, the $\mathrm{L} 2.5+\mathrm{G} 2.5$ treatment increased soil $\mathrm{Ca}_{\mathrm{Ex}}$ relative to the $\mathrm{C}$ treatment by $96-122 \%$ in the $0-20 \mathrm{~cm}$ soil layer and by $77-99 \%$ in the $20-40 \mathrm{~cm}$ soil layer (Figure $1 \mathrm{~d}$ ). In comparison, the $\mathrm{G}$ and $\mathrm{L}$ alone treatments increased $\mathrm{Ca}_{\mathrm{Ex}}$ by $49-72 \%$ compared to the $\mathrm{C}$ treatment in the $0-10 \mathrm{~cm}$ soil layer. In the MT, soil Ca $\mathrm{Ex}_{\mathrm{Ex}}$ for the L5.0 + G2.5 treatment was greater than the C by $46-141 \%$ in the $0-50 \mathrm{~cm}$ soil layer, (Figure 1e). In contrast, the $\mathrm{G}$ and $\mathrm{L}$ alone treatments had no significant effect on $\mathrm{Ca}_{\mathrm{Ex}}$. In the $\mathrm{LT}$, the L4, L8, and L4 + G2 treatments increased $\mathrm{Ca}_{\mathrm{Ex}}$ by $131-249 \%$ in the $0-20 \mathrm{~cm}$ soil layer and for the $\mathrm{L} 4+\mathrm{G} 2$ treatment by $94 \%$ in the $20-50 \mathrm{~cm}$ soil layer compared to the $\mathrm{C}$ treatment (Figure 1f). At the same time, soil $\mathrm{Ca}_{\mathrm{Ex}}$ content for the $\mathrm{L} 2$ treatment was greater by $139 \%$ in the $0-10 \mathrm{~cm}$ soil layer and by $77 \%$ in the $10-20 \mathrm{~cm}$ soil layer than the $\mathrm{C}$ treatment (Figure 1e). For the G2 treatment in the LT experiment, $\mathrm{Ca}_{\mathrm{Ex}}$ content was not significantly greater than the $\mathrm{C}$ treatment in the $0-20 \mathrm{~cm}$ soil layer.

Calcium recovery, as indicated by the increase in $\mathrm{Ca}_{\mathrm{Ex}}$ was low $(-2-31 \%)$ for all $\mathrm{L}$ treatments across the 3 three experiments (Table 2). In contrast, Ca recovery for the $G$ treatments was high (82-92\%) in the ST and MT but relatively low (48\%) in the LT while Ca recovery was low (23-37\%) for the L + G treatments for the three experiments.

Table 2. Recovery (\%) of the applied Ca from the $\mathrm{L}$ and $\mathrm{G}$ application as calculated by the difference in $\mathrm{Ca}_{\mathrm{Ex}}$ between the $\mathrm{L}$ and $\mathrm{G}$ treatments compared to the $\mathrm{C}$ treatment for the ST, MT, and LT experiments using soil samples collected in March 2018.

\begin{tabular}{|c|c|c|c|c|c|c|c|c|c|c|c|c|c|}
\hline \multicolumn{3}{|c|}{ ST } & \multicolumn{4}{|c|}{ MT } & \multicolumn{7}{|c|}{ LT } \\
\hline $\begin{array}{l}\text { Depth } \\
\text { (cm) }\end{array}$ & L2.5 & G2.5 & L2.5 + G2.5 & L2.5 & L5 & G2.5 & $\mathrm{L} 2.5+\mathrm{G} 2.5$ & L5.0 + G2.5 & L2 & L4 & L8 & G2.0 & $\mathrm{L} 4+\mathrm{G} 2$ \\
\hline $10-10$ & 7 & 20 & 10 & 0 & 3 & 33 & 5 & 11 & 6 & 5 & 5 & 14 & 9 \\
\hline 20-10 & 3 & 15 & 5 & 0 & 1 & 9 & 4 & 4 & 1 & 1 & 1 & 6 & 4 \\
\hline 30-10 & 2 & 8 & 3 & -1 & 0 & 12 & 5 & 4 & 0 & 1 & 1 & 3 & 2 \\
\hline
\end{tabular}

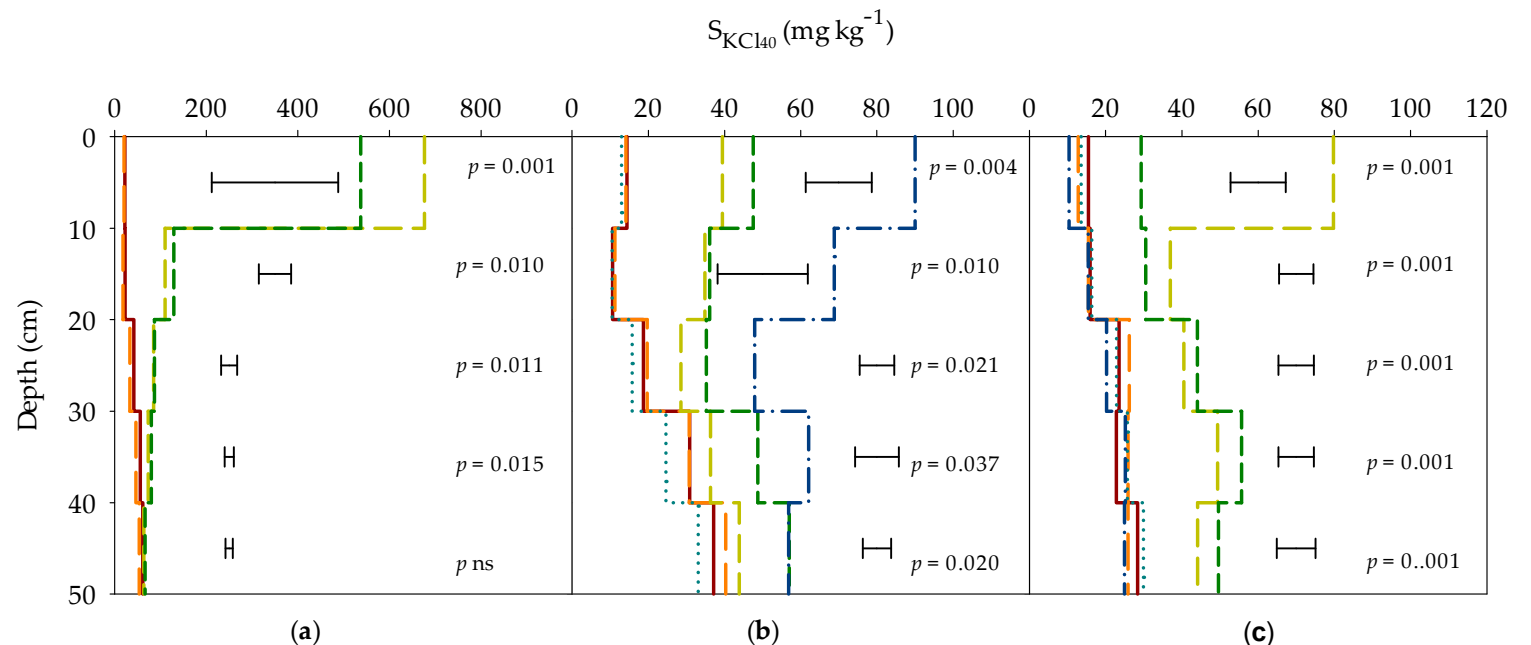

Figure 1. Cont. 


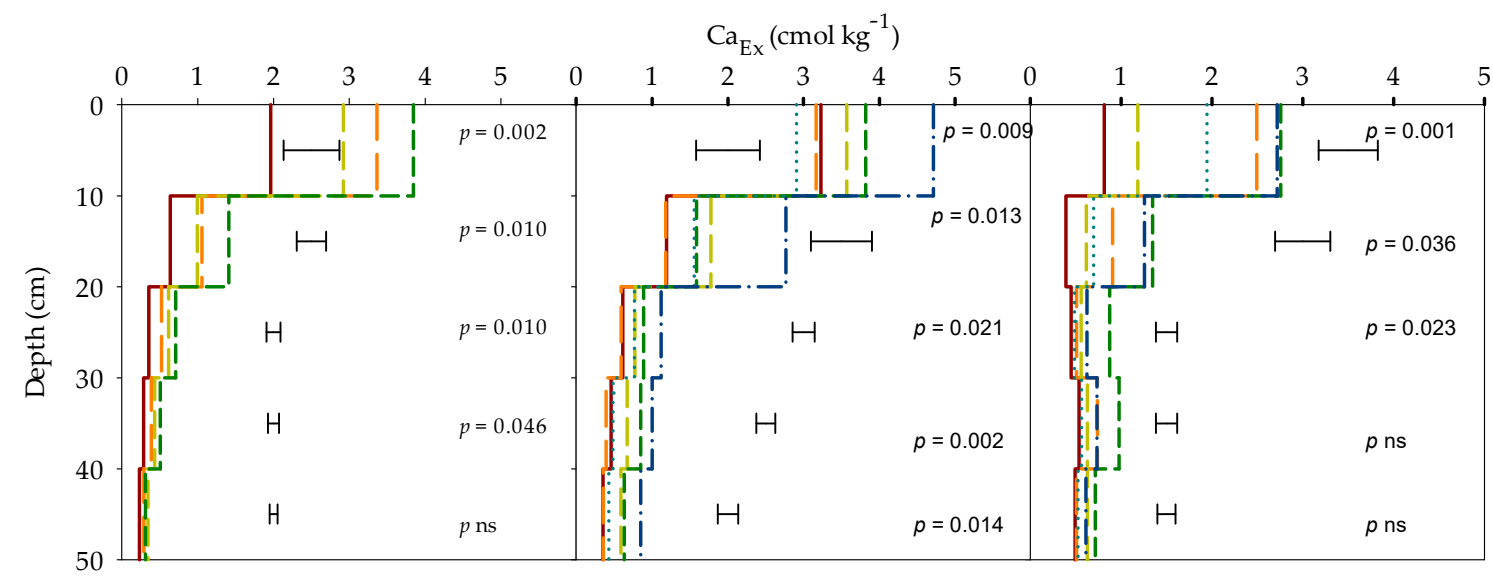

(d)

(e)

$(\mathbf{f})$

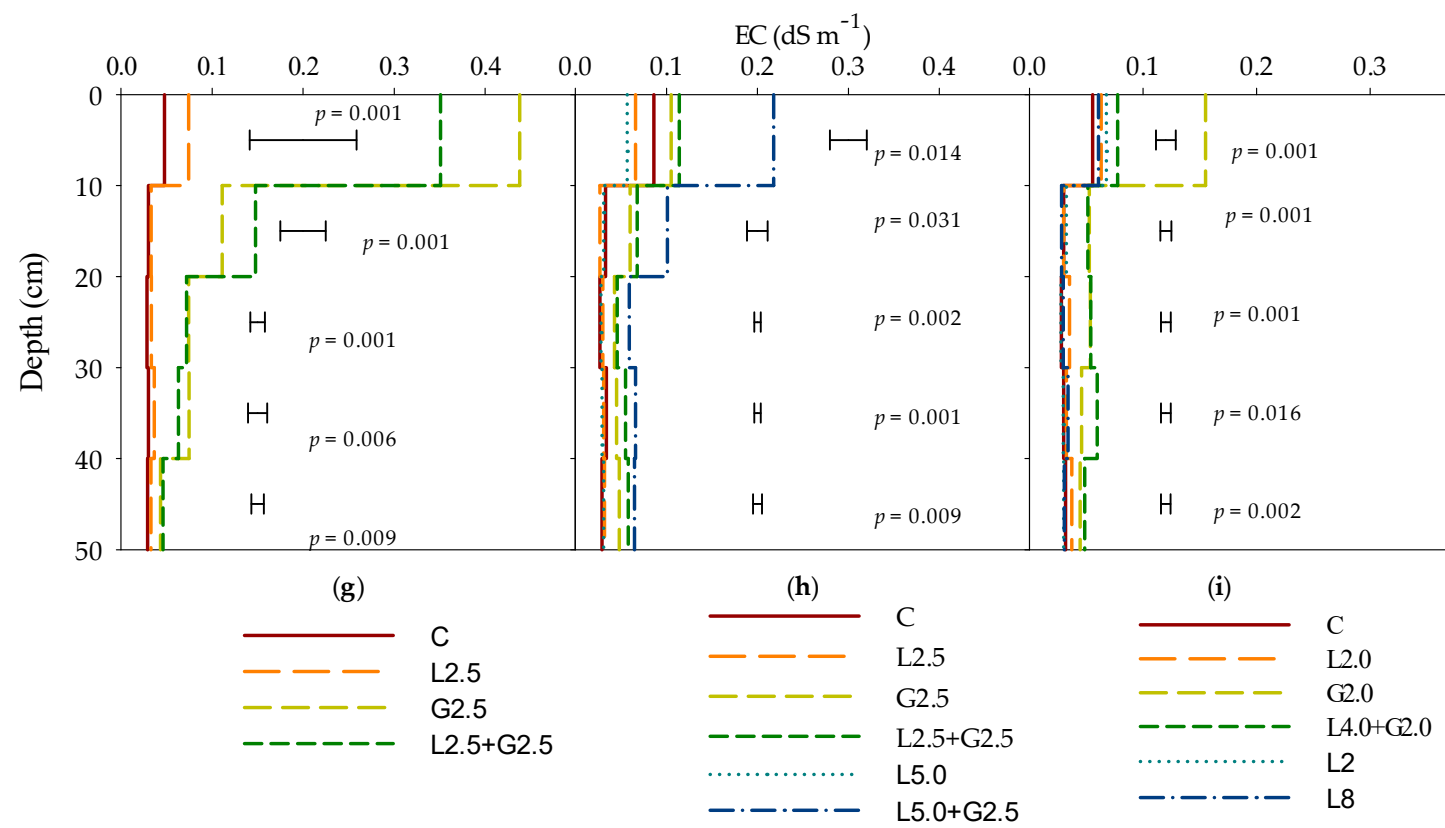

Figure 1. (a-c) Soil $\mathrm{S}_{\mathrm{KCl} 40,}(\mathbf{d}-\mathbf{f}), \mathrm{Ca}_{\mathrm{Ex}}$, and $(\mathbf{g}-\mathbf{i}) \mathrm{EC}(\mathbf{a}, \mathbf{d}, \mathbf{g})$ in the ST for C, L2.5, G2.5, L2.5 + G2.5 treatments $(\mathbf{b}, \mathbf{e}, \mathbf{h})$, in the MT for C, L2.5, G2.5, L2.5 + G2.5, L5.0, and L5.0 + G2.5 treatments and; $(\mathbf{c}, \mathbf{f}, \mathbf{i})$ in the LT for C, L4, G2, L4 + G2, L2, and L8 treatments. Error bars represent least significant difference values at $p=0.05, n=3$ for each depth with ns denoting $p>0.05$.

\subsection{Electrical Conductivity}

The application of L did not affect soil EC in the three experiments (Figure 1g-i). In contrast, the use of $\mathrm{G}$ resulted in a substantial increase in EC in the surface soil layers in the ST, and to lesser extents in the MT and LT. In the ST, the highest increase for the G treatments compared to the C and L2.5 treatments was in the $0-10 \mathrm{~cm}$ soil layer (636-490\%) declining to a $67-98 \%$ increase in the 30-40 $\mathrm{cm}$ soil layer (Figure 1g). There was also an increase of $28 \%$ for the L5.0 + G2.5 compared to the C treatment in the $40-50 \mathrm{~cm}$ soil layer. In the MT, EC values of the L5.0 + G2.5 treatment were $64-154 \%$ greater than the $C$ in the $0-50 \mathrm{~cm}$ soil layer (Figure $1 \mathrm{~h}$ ). In the LT, soil EC value for the $\mathrm{L} 4+\mathrm{G} 2$ treatment was $178 \%$ greater than the $C$ treatment in the $0-10 \mathrm{~cm}$ soil layer while for the G2 and L4 + G2 treatments EC was $41-93 \%$ greater than the $C$ in the $10-50 \mathrm{~cm}$ soil layer (Figure 1i). 


\subsection{Aluminum and $p H$}

For the $\mathrm{C}$ treatment, soil $\mathrm{Al}_{\mathrm{CaCl}_{2}}$ in the ST and MT experiments increased from $0.1-0.2 \mathrm{mg} \mathrm{Al} \mathrm{kg}{ }^{-1}$ in the $0-10 \mathrm{~cm}$ to $15.4-22.2 \mathrm{mg} \mathrm{Al} \mathrm{kg}^{-1}$ in the $40-50 \mathrm{~cm}$ (Figure 2a,b). In the LT experiment, the highest soil $\mathrm{Al}_{\mathrm{CaCl}_{2}}$ for the $\mathrm{C}$ treatment was $11.1-11.2 \mathrm{mg} \mathrm{Al} \mathrm{kg}^{-1}$ in the 10-30 $\mathrm{cm}$ (Figure 2c).

The $\mathrm{L}$ treatments decreased $\mathrm{Al}_{\mathrm{CaCl}_{2}}$, while $\mathrm{G}$ alone treatment had no impact on $\mathrm{Al}_{\mathrm{CaCl}_{2}}$. The extent and depth to which $\mathrm{L}$ application reduced on $\mathrm{Al}_{\mathrm{CaCl}_{2}}$ varied with time, $\mathrm{L}$ rate, and $\mathrm{G}$ application. In both the ST and MT experiment $\mathrm{L}, \mathrm{Al}_{\mathrm{CaCl}_{2}}$ is near zero in the $0-10 \mathrm{~cm}$ soil layers and hence was not lowered further by $\mathrm{L}$ application. In the ST, $\mathrm{L} \mathrm{G}$, and $\mathrm{L}+\mathrm{G}$ application decreased $\mathrm{Al}_{\mathrm{CaCl}_{2}}$ compared to the $C$ treatment by $48-69 \%$ in the $10-20 \mathrm{~cm}$ soil layer (Figure 2a).

In the $\mathrm{MT}, \mathrm{Al}_{\mathrm{CaCl}_{2}}$ was again near-zero and not lowered further by $\mathrm{L}$ application in $0-30 \mathrm{~cm}$ soil layer (Figure $2 \mathrm{~b}$ ). In contrast, $\mathrm{Al}_{\mathrm{CaCl}_{2}}$ was $74-91 \%$ lower for the $\mathrm{L} 5.0+\mathrm{G} 2.5$ treatment compared to the C treatment in the 30-50 cm soil layer with the difference significant at $p=0.054$ for the 30-40 cm soil layer. In the $\mathrm{LT}$, soil $\mathrm{Al}_{\mathrm{CaCl}_{2}}$ content for the $\mathrm{L}$ treatments was lower than the $\mathrm{C}$ treatment by $91-92 \%$ in the 0-10 cm (Figure 2c). In the 10-20 cm soil layer, $\mathrm{Al}_{\mathrm{CaCl}_{2}}$ content was $55 \%$ lower for the $\mathrm{L} 4$ treatment, and 77-95\% lower for the L4, L4 + G2, and L8 treatments than the C treatment. In the 20-30 cm soil layer, the $\mathrm{L} 4+\mathrm{G} 2$ treatment had a $70 \%$ lower $\mathrm{Al}_{\mathrm{CaCl}_{2}}$ than the $\mathrm{C}$ treatment.

Soil $\mathrm{Al}_{\mathrm{Ex}}$ in the ST and MT experiments, for the $\mathrm{C}$ treatment, increased with increasing soil depth from $0.09-0.10 \mathrm{cmol} \mathrm{kg}^{-1}$ in the $0-10 \mathrm{~cm}$ to $0.53-0.81 \mathrm{cmol} \mathrm{kg}^{-1}$ in the $40-50 \mathrm{~cm}$ soil layer (Figure $2 \mathrm{~d}$,e). In the LT experiment, the highest soil $\mathrm{Al}_{\mathrm{Ex}}$ for the $\mathrm{C}$ treatment of $0.36-0.45 \mathrm{cmol} \mathrm{kg}-1$ occurred in the $10-30 \mathrm{~cm}$ soil layer (Figure 2f).

In the $\mathrm{ST}$, the $\mathrm{L}$ and $\mathrm{G}$ treatments decrease $\mathrm{Al}_{\mathrm{Ex}}$ by $29-49 \%$ in the $10-20 \mathrm{~cm}$ soil layer (Figure $2 \mathrm{~d}$ ). In the MT, soil $\mathrm{Al}_{\mathrm{Ex}}$ was $48-62 \%$ lower for the G5.0 + L5.0 treatment than the $\mathrm{C}$ treatment in the $30-50 \mathrm{~cm}$ soil layer, with the difference significant at $p=0.062$ in the $40-50 \mathrm{~cm}$ soil layer (Figure 2e). In the $\mathrm{LT}$, soil $\mathrm{Al}_{\mathrm{Ex}}$ for the $\mathrm{L}$ and $\mathrm{L}+\mathrm{G}$ treatments was $72-86 \%$ lower in the $0-10 \mathrm{~cm}$ soil layer than the $\mathrm{C}$ treatment (Figure 2f). In the 10-20 cm soil layer, the $\mathrm{L} 4, \mathrm{~L} 4+\mathrm{G} 2$, and $\mathrm{L} 8$ treatments decreased $\mathrm{Al}_{\mathrm{Ex}}$ content by $53-72 \%$ compared to the $\mathrm{C}$ treatment. For the $\mathrm{L} 4+\mathrm{G} 2$ treatment, $\mathrm{Al}_{\mathrm{Ex}}$ content was $46-47 \%$ lower in the $20-30 \mathrm{~cm}$ soil layer compared to the $\mathrm{C}$ treatment. Application of $\mathrm{G} 2$ did not affect $\mathrm{Al}_{\mathrm{Ex}}$ in the $0-50 \mathrm{~cm}$ soil layer.

Soil $\mathrm{pH}_{\mathrm{CaCl}_{2}}$ in the ST and MT experiments, for the $\mathrm{C}$ treatment, decreased with increasing soil depth from $5.5-6.6$ in the $0-10 \mathrm{~cm}$ to $4.2-4.7$ in the $40-50 \mathrm{~cm}$ soil layer (Figure $2 \mathrm{~g}, \mathrm{~h}$ ). In the LT experiment, soil profile $\mathrm{pH}_{\mathrm{CaCl}_{2}}$ ranged between 4.5-4.7 (Figure 2i). In the ST and MT, neither L nor G application altered $\mathrm{pH}_{\mathrm{CaCl}_{2}}$ in any soil layers (Figure $2 \mathrm{~g}$,h). In the LT, soil $\mathrm{pH}_{\mathrm{CaCl}_{2}}$ ranged between 6.0-6.4 for the L4, L8, and L4 + G2 treatments compared to 4.6 for the $C$ treatment in the 0-10 cm soil layer (Figure 2i). Additionally, $\mathrm{pH}_{\mathrm{CaCl}_{2}}$ for the $\mathrm{L} 8$ treatment was greater at 5.1 compared to 4.5 for the $C$ treatment in the $10-20 \mathrm{~cm}$ soil layer at $p=0.066$.

The relationships between $\mathrm{pH}_{\mathrm{CaCl}_{2}}$ and $\mathrm{Al}_{\mathrm{CaCl}_{2}}$ were similar for the three experimental sites (Figure 3). In the LT experiment, the $\mathrm{L}$ treatments decreased $\mathrm{Al}_{\mathrm{CaCl}_{2}}$ from 11.3 to $2.8 \mathrm{mg} \mathrm{Al} \mathrm{kg}{ }^{-1}$ with the associated change in $\mathrm{pH}_{\mathrm{CaCl}_{2}}$, ranging from 4.4 to 4.6. The lowest $\mathrm{pH}_{\mathrm{CaCl}_{2}}$ and greatest $\mathrm{Al}_{\mathrm{CaCl}_{2}}$ occurred in the $20-50 \mathrm{~cm}$ soil layer for the ST experiment, in the $30-50 \mathrm{~cm}$ soil layer for the MT experiment, and in the 10-30 cm soil layer for the LT experiment (Figure 2). Soil $\mathrm{pH}_{\mathrm{CaCl}_{2}}$ and $\mathrm{Al}_{\mathrm{CaCl}_{2}}$ were both related to $\mathrm{Al}_{\mathrm{Ex}}$ (Figure 4). The relationships and equations used to convert $\mathrm{Al}_{\mathrm{CaCl}_{2}}$ to $\mathrm{Al}_{\mathrm{Ex}}$ are presented in Figure 4. 


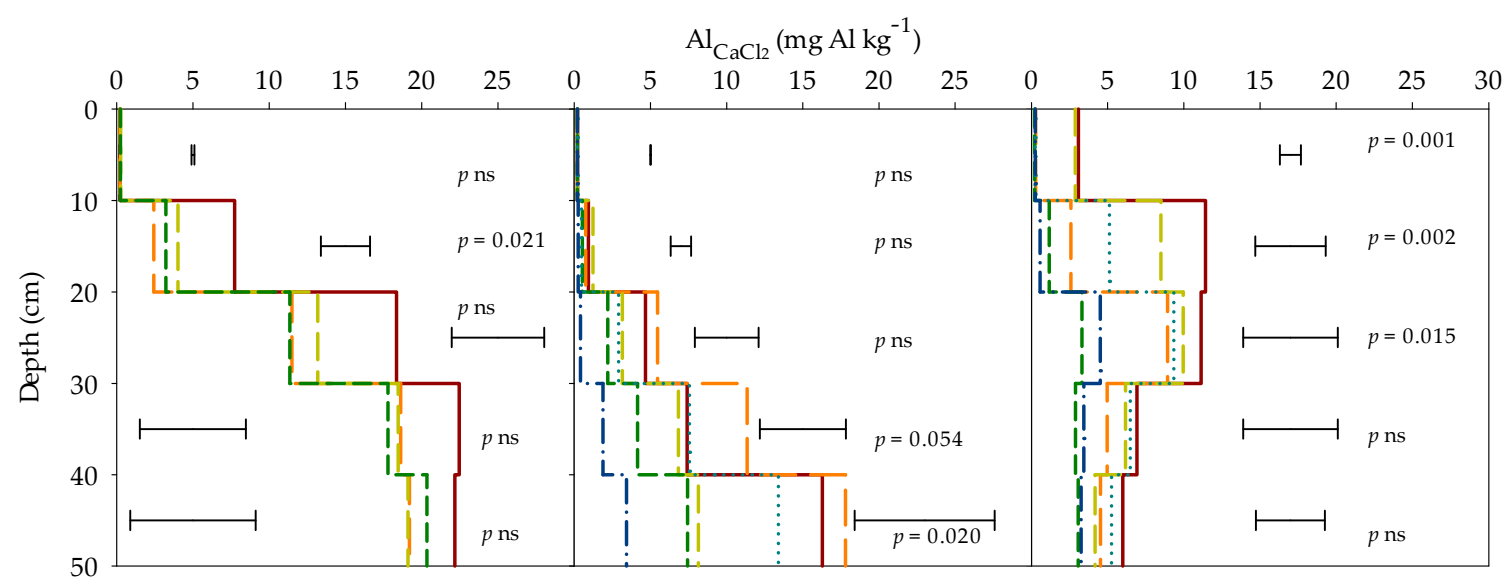

(a)

(b)

(c)

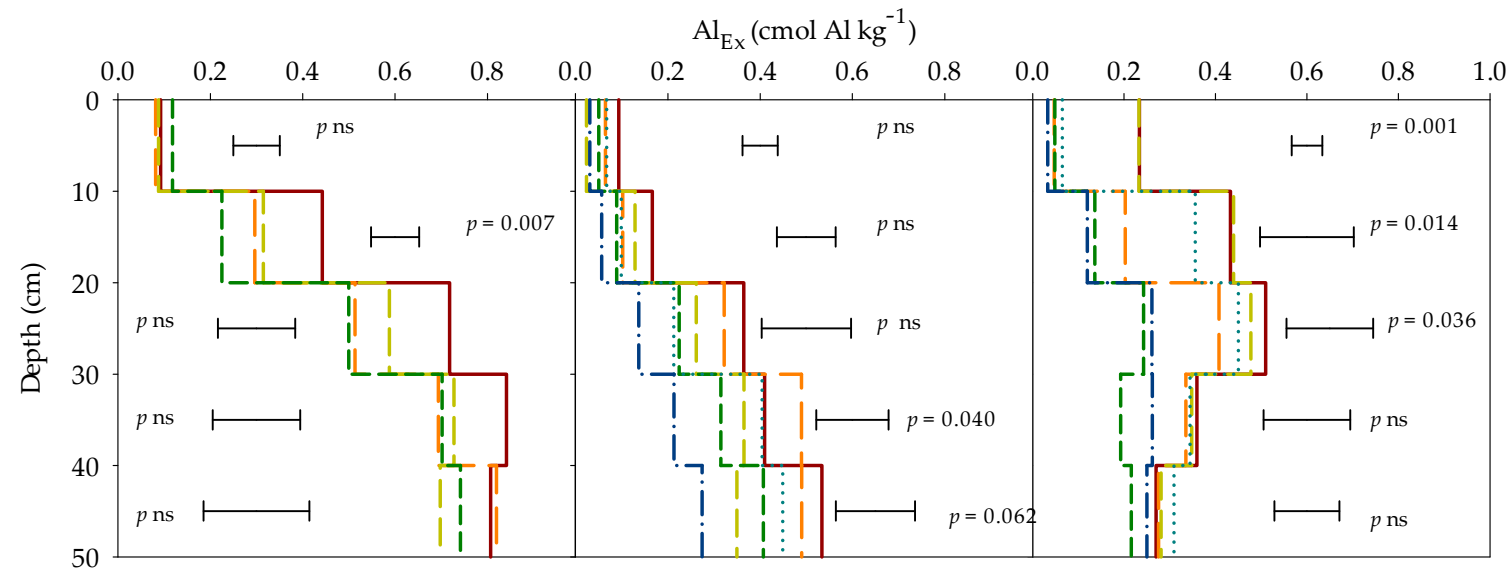

(d)

(e)

(f)

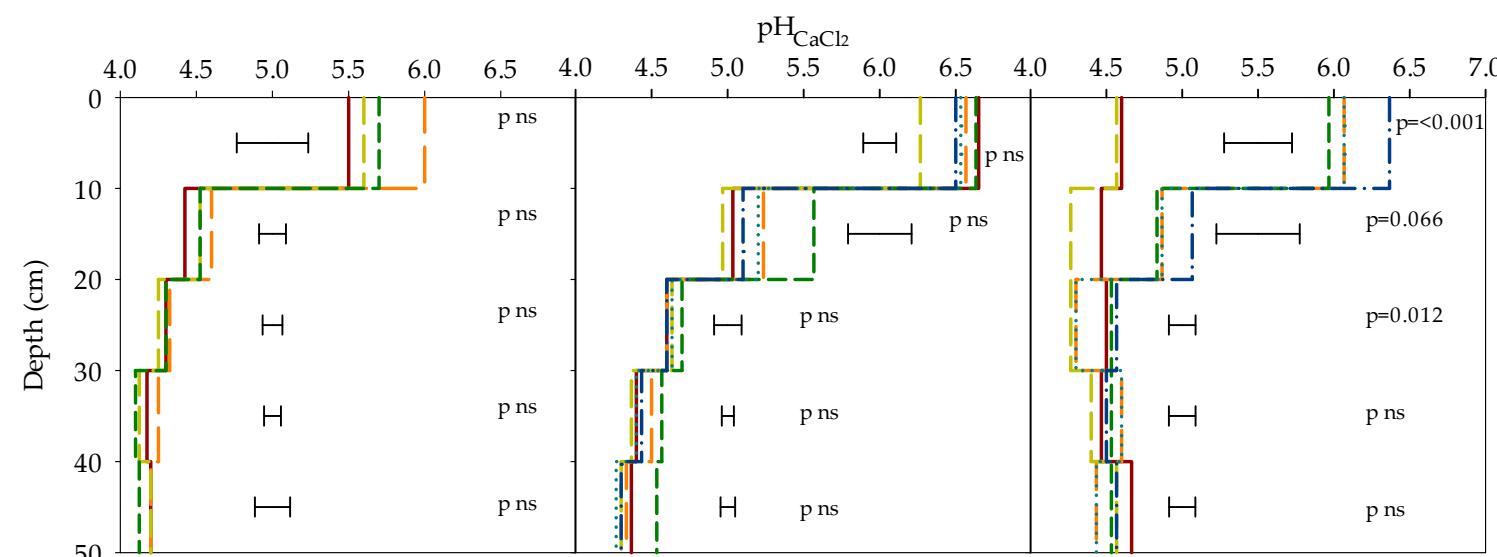

(g)

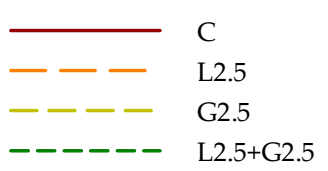

(h)

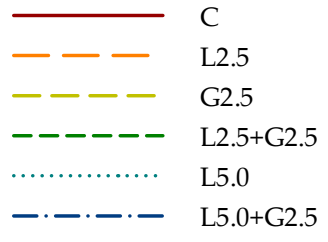

(i)

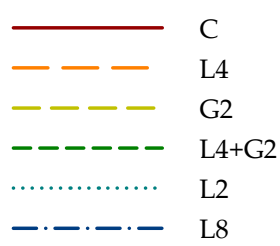

Figure 2. (a-c) Soil $\mathrm{Al}_{\mathrm{CaCl}_{2}},(\mathbf{d}-\mathbf{f}) \mathrm{Al}_{\mathrm{Ex}}$, and $(\mathbf{g}-\mathbf{i}) \mathrm{pH}_{\mathrm{CaCl}_{2}}(\mathbf{a}, \mathbf{d}, \mathbf{g})$ in the ST for C, L2.5, G2.5, L2.5 + G2.5 treatements (b,e,h), in the MT for C, L2.5, G2.5, L2.5 + G2.5, L5.0, and L5.0 + G2.5 treatments; and $(\mathbf{c}, \mathbf{f}, \mathbf{i})$ and in the LT for C, L4, G2, L4 + G2, L2, and L8 treatments. Error bars represent least significant difference values at $p=0.05, n=3$ for each depth with ns denoting $p>0.05$. The exceptions were in (e) for the 40-50 cm where $p=0.062$ and (i) for the 10-20 cm where $p=0.066$. 


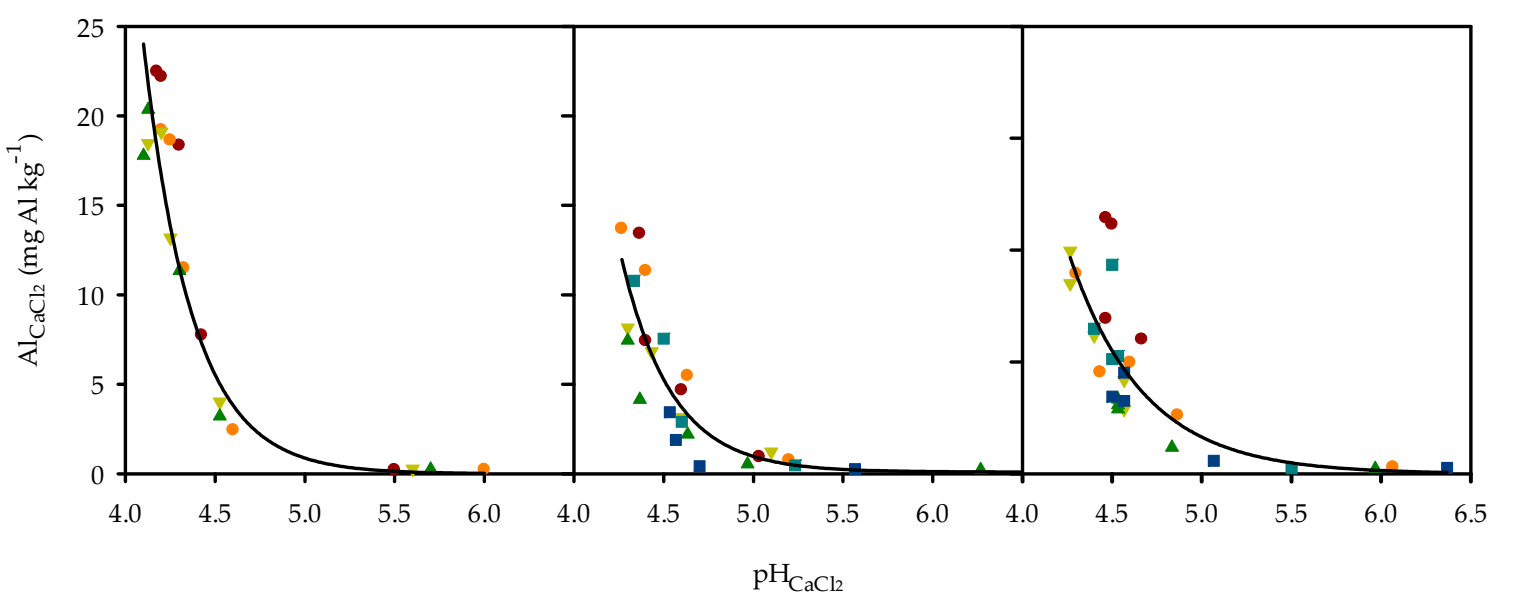

(a)

(b)

(c)

Figure 3. (a) Relationship between $\mathrm{pH}_{\mathrm{CaCl}_{2}}$ and $\mathrm{Al}_{\mathrm{CaCl}_{2}}(\mathrm{mg} \mathrm{Al} \mathrm{kg}$ ) across sampling depths for the ST $\left(\mathrm{Al}_{\mathrm{CaCl}_{2}}=\left(85,221,378 \times \exp \left(-3.67 \times \mathrm{pH}_{\mathrm{CaCl}_{2}}\right), \mathrm{r}^{2}=0.94 ;(\mathbf{b}) \mathrm{MT}\left(\mathrm{Al}_{\mathrm{CaCl}_{2}}=0.09+(47,860,313 \times\right.\right.\right.$ $\left.\exp \left(-3.56 \times \mathrm{pH}_{\mathrm{CaCl}_{2}}\right), \mathrm{r}^{2}=0.78\right) ;$ and (c) $\mathrm{LT}\left(\mathrm{Al}_{\mathrm{CaCl}_{2}}=0.001+\left(292,525 \times \exp \left(-2.41 \times \mathrm{pH}_{\mathrm{CaCl}_{2}}\right), \mathrm{r}^{2}=0.60\right.\right.$ experiments for the various L and G treatments measured in March 2018. The ST, MT, and LT; L and G treatments are C $(\bullet), \mathrm{L} 2.5(\nabla), \mathrm{G} 2.5(\bullet)$, and L2.5+G2.5 $(\diamond)$. The additional treatments in the MT are; L5.0 ( $\square)$ and L5.0+G2.5 ( $\square)$; and in the LT are L2 ( $\square)$ and L8 ( $\square)$.

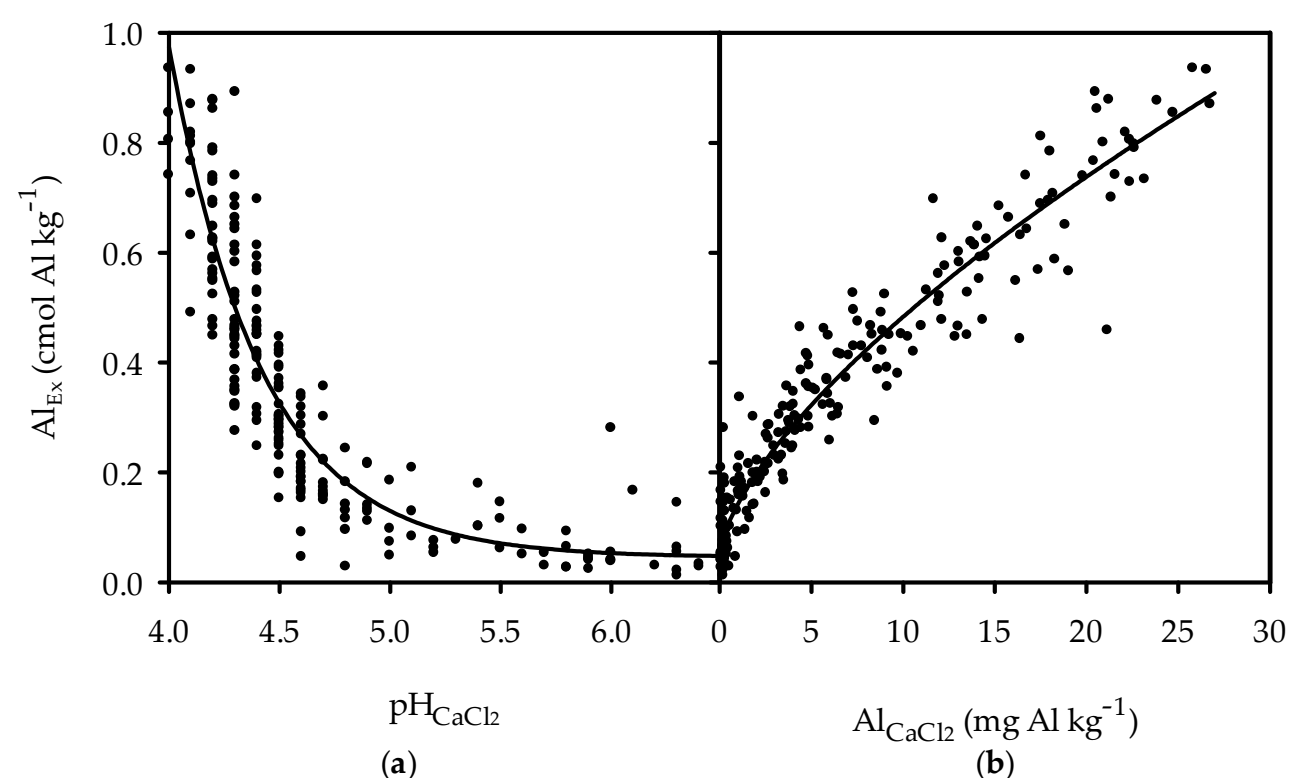

Figure 4. (a) Relationship between $\mathrm{pH}_{\mathrm{CaCl}_{2}}$ and $\mathrm{Al}_{\mathrm{Ex}}: \mathrm{Al}_{\mathrm{Ex}}=0.04+\left(13,648 \times \exp \left(-2.40 \times \mathrm{pH}_{\mathrm{CaCl}_{2}}\right)\right.$, $\mathrm{r}^{2}=0.82 ;$ and (b) $\mathrm{Al}_{\mathrm{CaCl}_{2}}$ and $\mathrm{Al}_{\mathrm{Ex}}, \mathrm{Al}_{\mathrm{Ex}}=0.05+\left(0.093 \times\left(\mathrm{Al}_{\mathrm{CaCl}_{2}}{ }^{0.668}\right), \mathrm{r}^{2}=0.93\right.$.

\subsection{Effective Cation Exchange Capacity}

Soil ECEC of the soil profile, in the three experiments, decreased with increasing soil depth from $1.51-2.40 \mathrm{cmol} \mathrm{kg}^{-1}$ in the $0-10 \mathrm{~cm}$ to $1.07-1.15 \mathrm{cmol} \mathrm{kg}^{-1}$ in the $40-50 \mathrm{~cm}$ soil layer (Figure 5). In the ST, soil ECEC for the $L$ and $G$ treatments was $44-87 \%$ greater than the $C$ treatment in the $0-10 \mathrm{~cm}$ soil layer while ECEC was 16-50\% greater for the L2.5 + G2.5 treatment was than the $C$ in the 10-30 cm soil layer. In the MT, ECEC of the L5.0 + G2.5 treatment was greater than the C, L2.5, and L5.0 treatments by $27-96 \%$ in the $0-50 \mathrm{~cm}$ soil layer (Figure $5 b$ ). In the LT, ECEC for the L2 treatment was $56-65 \%$ greater in the $0-20 \mathrm{~cm}$ soil layer compared to the C treatment (Figure 5c). For the L4, L8, and L4 + G2 treatments ECEC was $90-148 \%$ greater in the $0-20 \mathrm{~cm}$ soil layer compared to the $C$ treatment. Soil ECEC for the G2 treatment was the same as the $C$ treatment. 


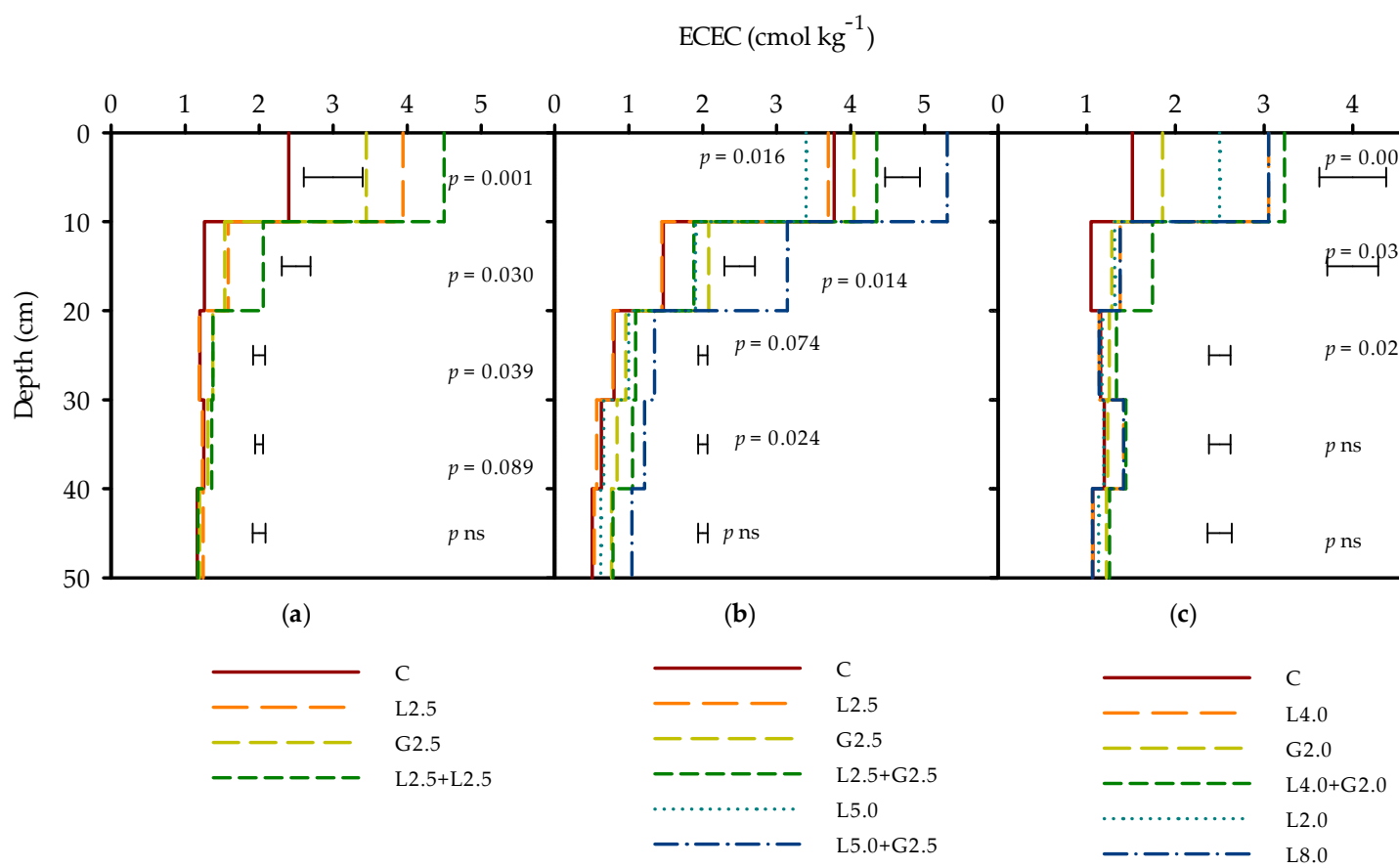

Figure 5. (a) Soil ECEC in the ST for C, L2.5, G2.5, L2.5 + G2.5 treatments, (b) in the MT for C, L2.5, G2.5, L2.5 + G2.5, L5.0, and L5.0 + G2.5 treatments; and (c) in the LT for C, L4, G2, L4 + G2, L2, and L8 treatments. Error bars represent least significant difference values at $p=0.05, n=3$ for each depth with ns denoting $p>0.05$.

\section{Discussion}

\subsection{Sulfate}

Leaching of soil $\mathrm{SO}_{4}-\mathrm{S}$ occurs in light texture soils of South Western Australia due to the low water holding capacity of the soil profile, high June and July rainfall and limited adsorption of $\mathrm{SO}_{4}-\mathrm{S}$ [15]. The soil profile for the LT experiment had SBI of 10-14, indicating the soil has a low capacity to adsorb $\mathrm{SO}_{4}-\mathrm{S}$ [13]. The soil profiles at the other two experimental sites had a greater ability to adsorb $\mathrm{SO}_{4}-\mathrm{S}$, especially in the soil layers below $10 \mathrm{~cm}$ with SBI of 9-36. Due to this combination of rainfall, water holding capacity of the soil, and $\mathrm{SO}_{4}-\mathrm{S}$ adsorbing capacity, $\mathrm{SO}_{4}-\mathrm{S}$ derived from $\mathrm{G}$ was readily leached into and through the soil profile. In the $\mathrm{ST}$ experiment, $\mathrm{SO}_{4}-\mathrm{S}$ was leached rapidly into the soil profile, as measured by the increase $\mathrm{S}_{\mathrm{KCl} 40}$ content, even after a relatively low rainfall $(279 \mathrm{~mm})$ growing season (Figure 1a). The increase in $\mathrm{S}_{\mathrm{KCl} 40}$ was associated with increased EC (Figure 1g) and $\mathrm{Al}_{-} \mathrm{SO}_{4}$ [24], leading to an increasing canola grain yield in the first year after application [3]. In retrospect, in the ST, to cope with the variation observed following a recent application of $G$, we should have collected more soil cores to define the $\mathrm{G}$ effect on $\mathrm{S}_{\mathrm{KCl} 40}$ measurement accurately. In the MT and LT, the effectiveness of $\mathrm{G}$ declines [3] because $\mathrm{SO}_{4}$-S is leached below the $50 \mathrm{~cm}$ sampling depth as indicated by the low recovery of the applied $\mathrm{SO}_{4}-\mathrm{S}(28-54 \%)$ (Table 1$)$.

The leaching of $\mathrm{SO}_{4}-\mathrm{S}$ can also occur within 3.5 years, even for soils with high $\mathrm{SO}_{4}-\mathrm{S}$ adsorption capacities [12]. In the LT, G application increased $\mathrm{S}_{\mathrm{KCl} 40}$ content resulting in the retention of $26-27 \%$ of the applied $\mathrm{SO}_{4}$-S within $0-50 \mathrm{~cm}$ soil layer (Table 1). Retention of $\mathrm{SO}_{4}-\mathrm{S}$ was also observed in the subsoil 13 years after the $\mathrm{G}$ application due to the high $\mathrm{SO}_{4}-\mathrm{S}$ adsorption capacity [12]. Soils retain $\mathrm{SO}_{4}-\mathrm{S}$ by the processes of adsorption and precipitation [25]. The precipitation of $\mathrm{Al}_{-} \mathrm{SO}_{4}$ is more critical in soils with high $\mathrm{Al}$ content which occurs in soil with $\mathrm{pH}_{\mathrm{CaCl}_{2}}$ less than 4.5 [26]. Soil with greater $\mathrm{pH}_{\mathrm{CaCl}_{2}}$ has a lower ability to adsorb $\mathrm{SO}_{4}$-S due to decreases in anion exchange capacity on variable charge surfaces [27]. Hence, $\mathrm{L}$ application which increases soil $\mathrm{pH}$ results in lower retention of $\mathrm{SO}_{4}-\mathrm{S}$ or lower $\mathrm{S}_{\mathrm{KCl} 40}$ content in the $0-20 \mathrm{~cm}$ for the LT experiment (Figure 1c). We have confirmed the retention 
of $\mathrm{SO}_{4}-\mathrm{S}$ as $\mathrm{Al}-\mathrm{SO}_{4}$ for these experiments using soil solution and modelling approach [24]. However, in the LT, the lower wheat grain yield response to the $\mathrm{G}$ treatment occurs over time is attributed to the leaching of $\mathrm{SO}_{4}-\mathrm{S}$ below the $\mathrm{Al}^{3+}$ toxic layer $(10-40 \mathrm{~cm})[3]$.

\subsection{Calcium}

In general, the effect of the application of $\mathrm{L}$ and $\mathrm{G}$ is to increase $\mathrm{Ca}_{\mathrm{Ex}}$ (Figure $1 \mathrm{~d}-\mathrm{f}$ ), and decrease $\mathrm{Al}_{\text {Ex }}$ (Figure 2d-f) with the net result an increase in ECEC (Figure 5a-c) [28]. Leaching of Ca derived from $G$ and $L$ varies according to application rates, time of contact with the soil and soil properties [17]. In these experiments, we applied Ca at different rates of $L$ and $G$, and it was not possible to directly compare the leaching rates of the two Ca sources. Nevertheless, in the LT experiment, the application of $L$ and $G$ together resulted in an increase in soil CaEx to a depth of $30 \mathrm{~cm}$ compared to only $20 \mathrm{~cm}$ when only L8 or G was applied (Figure 1f). Similarly, the combined application of L and G increased $\mathrm{Ca}_{\mathrm{Ex}}$ to a greater depth than the use of only L or G on soils in southern Brazil [17].

\subsection{Electrical Conductivity}

The EC of Tenosols of South Western Australia is generally less than $0.11 \mathrm{dS} \mathrm{m}^{-1}$ due to the highly weathered and leached nature of the soil [29]. EC is an important measurement when examining subsoil $\mathrm{Al}$ toxicity limitations because soils with greater $\mathrm{EC}$ decreases $\mathrm{Al}^{3+}$ activity and increases ion paring, which together makes the solution $\mathrm{Al}^{3+}$ less toxic [30]. For example, soils with greater $\mathrm{EC}$ have a lower critical $\mathrm{Al}_{\mathrm{Ex}} \%$ value [31]. In the three present experiments, EC was less than $0.07 \mathrm{dS}$ $\mathrm{m}^{-1}$ in the soil profile (Figure $1 \mathrm{~g}-\mathrm{i}$ ). The critical range for tolerant wheat cultivars to achieve $90 \%$ of maximum grain yield is between 21-32 $\mathrm{Al}_{\mathrm{Ex}} \%$, which is equivalent to $\mathrm{Al}_{\mathrm{CaCl}_{2}}$ of $3.9-7.0 \mathrm{mg} \mathrm{Al} \mathrm{kg}{ }^{-1}$ (Figure $4 \mathrm{~b}$ ). For the three experimental sites, $\mathrm{Al}_{\mathrm{Ex}} \%$ for the sampling depth $10-30 \mathrm{~cm}$ ranged between $10-59 \%$ indicating $\mathrm{Al}$ toxicity at levels that would reduce wheat grain yield. In these experiments, the application of $\mathrm{G}$ increased soil EC to $\geq 0.07 \mathrm{dS} \mathrm{m}^{-1}$ in the $0-30 \mathrm{~cm}$ soil layer in the ST (Figure $1 \mathrm{~g}$ ). This increase in $\mathrm{EC}$ reduced the critical range $13-21 \mathrm{Al}_{\mathrm{Ex}} \%$, which is equivalent to $\mathrm{Al}_{\mathrm{CaCl}_{2}}$ of $2.0-3.9 \mathrm{mg} \mathrm{kg}^{-1}$ and is more consistent with the critical range observed by [2]. The increase in EC due to $\mathrm{G}$ application is, therefore, likely to have contributed to reducing the adverse effects of subsoil $\mathrm{Al}^{3+}$ toxicity and increased grain yield [3].

\subsection{Aluminum and $\mathrm{pH}$}

Leaching of alkalinity derived from dissolved $\mathrm{L}$ occurs when $\mathrm{pH}_{\mathrm{CaCl}_{2}}$ of the $0-10 \mathrm{~cm}$ soil layer is greater than 5.5 [32]. When $\mathrm{L}$ is applied, both $\mathrm{Ca}$, and $\mathrm{Mg}$ cations are leached, suggesting the ions are moving as $\mathrm{Ca}$ and $\mathrm{Mg}$ bicarbonate [12]. Once $\mathrm{pH}_{\mathrm{CaCl}_{2}}$ of the $0-10 \mathrm{~cm}$ soil layer has achieved a $\mathrm{pH}_{\mathrm{CaCl}_{2}}$ of 7.1, L will stop dissolving [33,34]. Due to this restriction on $\mathrm{L}$ dissolution, the pool of alkalinity available to be leached into the subsoil is insufficient for the $\mathrm{L}$ application to have an impact on subsoil $\mathrm{pH}[2,32,35,36]$. In the ST and MT experiments, $\mathrm{pH}_{\mathrm{CaCl}_{2}}$ in the $0-10 \mathrm{~cm}$ soil layer was greater than 5.5, and the application of additional $\mathrm{L}$ resulted in no impact on subsoil $\mathrm{pH}_{\mathrm{CaCl}_{2}}$ over the sampling period of two years and eight months. In the LT, a high rate of $\mathrm{L}$ application $\left(4-8 \mathrm{tha}^{-1}\right)$ increased $\mathrm{pH}_{\mathrm{CaCl}_{2}}$ in the $10-20 \mathrm{~cm}$ soil layer while $2 \mathrm{t} \mathrm{L} \mathrm{ha}{ }^{-1}$ did not affect subsoil $\mathrm{pH}_{\mathrm{CaCl}_{2}}$ (Figure $2 \mathrm{i}$ ). This observation is consistent with other studies that have shown $\mathrm{L}$ application can be slow or in some cases, ineffective in increasing subsoil $\mathrm{pH}_{\mathrm{CaCl}_{2}}[2,35,36]$.

There are a diverse array of chemical reactions that can arise when $\mathrm{G}$ is applied, resulting in a change in soil $\mathrm{pH}$ [37]. In soils with a high capacity for $\mathrm{SO}_{4}$-S sorption, the net effect is an increase in soil $\mathrm{pH}_{\mathrm{CaCl}_{2}}$ [12]. In contrast, the LT experiment soil profile has an SBI of 10-14, indicating a low ability to sorb $\mathrm{SO}_{4}-\mathrm{S}$, [3]. Hence, the net effect of $\mathrm{G}$ application on the low SBI was no significant impact on soil $\mathrm{pH}_{\mathrm{CaCl}_{2}}$ in the 10-30 cm soil layer (Figure 2i). Nevertheless, small changes in the $\mathrm{pH}_{\mathrm{CaCl}_{2}}$ within the range of 4.3-4.5 can result in significant changes in $\mathrm{Al}_{\mathrm{CaCl}_{2}}$ (Figure 4). However, in this case, G application did not affect $\mathrm{Al}_{\mathrm{CaCl}_{2}}$ compared to the $\mathrm{C}$ treatment in the $10-20 \mathrm{~cm}$ soil layer (Figure 2c). 
Application of $\mathrm{L}$ to the soil surface resulted in a more significant decline in soil $\mathrm{Al}$ values $\left(\mathrm{Al}_{\mathrm{CaCl}_{2}}\right.$ and $\mathrm{Al}_{\mathrm{Ex}}$ ) than the increase in $\mathrm{pH}_{\mathrm{CaCl}_{2}}$ in the soil layers below $10 \mathrm{~cm}$ because there is an exponential relationship between $\mathrm{pH}_{\mathrm{CaCl}_{2}}$ and these soil $\mathrm{Al}$ measurements (Figures 3 and 4a). Hence, for small changes in $\mathrm{pH}_{\mathrm{CaCl}_{2}}$ below 4.5, there is a greater change in $\mathrm{Al}_{\mathrm{CaCl}_{2}}$ and $\mathrm{Al}_{\mathrm{Ex}}$. Therefore, both $\mathrm{Al}_{\mathrm{CaCl}_{2}}$ and $\mathrm{Al}_{\mathrm{Ex}}$ are a more sensitive measurement of the impact of $\mathrm{L}$ application on soil properties than $\mathrm{pH}_{\mathrm{CaCl}_{2}}$. For example in the LT experiment, $\mathrm{L} 8$ resulted in a 50-92\% decrease in the $\mathrm{Al}_{\mathrm{CaCl}_{2}}$ content to a depth of $40 \mathrm{~cm}$ (Figure 2c) compared to $\mathrm{pH}_{\mathrm{CaCl}_{2}}$ which only increased from 4.6 to 5.1 in the $10-20 \mathrm{~cm}$ soil layer (Figure 2i). Furthermore, in the MT experiment, the L2.5 + G2.5 treatment resulted in a 54-84\% reduction in soil $\mathrm{Al}_{\mathrm{CaCl}_{2}}$ in the soil layers 20-50 $\mathrm{cm}$ (Figure 2e) and no effect subsoil $\mathrm{pH}_{\mathrm{CaCl}_{2}}$ (Figure 2h). These observations are consistent with other experiments that observed the application of $\mathrm{L}$ decreased $\mathrm{Al}_{\mathrm{Ex}}$ to a greater depth than the decrease in $\mathrm{pH}_{\mathrm{CaCl}_{2}}$ [38-40]. For example, in an experiment monitored over time, application of $6 \mathrm{t} \mathrm{L} \mathrm{ha}{ }^{-1}$ increased $\mathrm{pH}_{\mathrm{CaCl}_{2}}$ in the $10-20 \mathrm{~cm}$ soil layer by $0.2-0.4 \mathrm{pH}$ units after 2.5 years with the effect remaining constant over time while $\mathrm{Al}_{\mathrm{Ex}}$ decrease by $55 \%$ after 2.5 years and to $68 \%$ after ten years [41]. However, reductions in $\mathrm{Al}_{\mathrm{CaCl}_{2}}$ and $\mathrm{Al}_{\mathrm{Ex}}$ observed for the $\mathrm{L} 8$ treatment did not increase crop grain yield compared to the L2 treatment [3].

An effective LT strategy is to apply sufficient $\mathrm{L}$ to maintain the soil $\mathrm{pH}_{\mathrm{CaCl}_{2}}$ of the $0-10 \mathrm{~cm}$ greater than 5.5 because it will maximize the impact that a surface $\mathrm{L}$ application will have on the subsoil $\mathrm{Al}$ toxicity content [32]. In the LT experiment, 4-8 $\mathrm{t} \mathrm{h} \mathrm{ha}^{-1}$ resulted in a $\mathrm{pH}_{\mathrm{CaCl}_{2}}$ of greater than 6.1 in the 0-10 cm soil layer measured in March 2018, but the treatments did not affect $\mathrm{pH}_{\mathrm{CaCl}_{2}}$ in the 20-30 cm soil layer (Figure 2c). In contrast, $\mathrm{L}$ and $\mathrm{G}$ have a synergistic effect on soil $\mathrm{Al}$ toxicity by increasing alkalinity leaching as indicated by a more significant decline in $\mathrm{Al}_{\mathrm{CaCl}_{2}}$ and $\mathrm{Al}_{\mathrm{Ex}}$ in the $\mathrm{MT}$ (Figure $2 \mathrm{~b}, \mathrm{e}$ ). In retrospect, to account for the high variability, we should have collected more soil cores than 4 to define this effect better. In the LT experiment, the L4 + G2 treatment resulted in a greater and deeper decline in $\mathrm{Al}_{\mathrm{CaCl}_{2}}$ and $\mathrm{Al}_{\mathrm{Ex}}$ compared to the $\mathrm{L} 4$ treatment (Figure 2c,f). Other researchers have also hypothesized the combined application of $\mathrm{L}$ and $\mathrm{G}$ could have a synergistic effect in improving soil chemical properties and crop grain yields as observed by for highly acidic subsoil $[6,42,43]$. However, the response was not consistent between sampling years at another experiment conducted located near the ST experimental site [6]. Additionally, in high rainfall subtropical region, the combined use of $L$ and $G$ had no synergistic effect in improving soil chemical properties and crop grain yields [44]. In that agricultural system and soil, surface application of $\mathrm{L}$ was effective in increasing $\mathrm{pHmeasured}$ using water as the extracting solution to a depth of $60 \mathrm{~cm}$ within the first year. In contrast, in the South Western Australia agricultural region $\mathrm{L}$ application can be ineffective in increasing subsoil $\mathrm{pH}_{\mathrm{CaCl}_{2}}$ [2]. Hence, the synergistic $L$ and $G$ effect in improving soil chemical properties and crop grain yields could play a significant role in South Western Australia. However, further research is required to examine the combination of soil and growing environments where this effect occurs.

\section{Conclusions}

The combined application of lime and gypsum is more effective than applying lime alone in managing subsoil Al constraints for crop production in the short-term (1 year) due to the increased soil sulfate, calcium and electrical conductivity of the subsoil with the application of gypsum even following relatively dry year $(279 \mathrm{~mm})$. Use of lime and gypsum together in the medium-term (two years and eight months) and long-term (ten years) lead to a decrease in soil $\mathrm{Al}$, to a greater depth than the application of lime only. The impact of broadcast lime plus gypsum and lime alone resulted in changes in subsoil $\mathrm{Al}$ measurements to a greater depth than changes in soil $\mathrm{pH}$, indicating soil $\mathrm{Al}$ measurements are more sensitive than soil $\mathrm{pH}$ measurements.

Author Contributions: Conceptualization, G.C.A., S.P., D.J.M.H. and J.E.; Data curation, S.P. and J.E.; Formal analysis, G.C.A., S.P. and J.E.; Funding acquisition, D.J.M.H. and J.E.; Investigation, G.C.A., S.P., D.J.M.H., J.E., and R.S.; Methodology, G.C.A., S.P., D.J.M.H. and J.E.; Project administration, D.J.M.H. and J.E.; Resources, D.J.M.H.; Supervision, D.J.M.H. and J.E.; Writing-original draft, G.C.A.; Writing-review \& editing, G.C.A., S.P., D.J.M.H., R.S., and J.E. All authors read and approved the final manuscript. 
Funding: This research was funded by Grain Research and Development Corporation project number DAW00242, Department of Primary Industries and Regional Development and CSBP.

Acknowledgments: Warakarri Cropping managed the ST and MT experiments.

Conflicts of Interest: The authors declare no conflict of interest.

\section{References}

1. Ritchie, G.S.P. Soluble aluminium in acidic soils: Principles and practicalities. In Plant Soil Interactions at Low pH; Date, R.A., Grundon, N.J., Rayment, G.E., Probert, M.E., Eds.; Kluwer Academic Publishers: Dordrecht, The Netherlands, 1995; pp. 23-33.

2. Anderson, G.C.; Bell, R.W. Wheat grain-yield response to lime application: Relationships with soil $\mathrm{pH}$ and aluminium in Western Australia. Crop. Pasture Sci. 2019, 70, 295-305. [CrossRef]

3. Anderson, G.C.; Pathan, S.; Hall, D.J.M.; Sharma, R.; Easton, J. Short and long term effects of lime and gypsum application on acid soils in a water-limited environment 1. Grain yield response and nutrient concentration. Agronomy 2020, 10, 1213. [CrossRef]

4. Lebedev, A.; Kosorukov, V.L. Gypsum solubility in water at $25^{\circ} \mathrm{C}$. Geochem. Int. 2017, 55, 205-210. [CrossRef]

5. Aylward, G.H.; Findlay, T.J.V. SI Chemical Data Book, 6th ed.; John Wiley and Sons: Chichester, UK, 2008; ISBN 978-0-730-30246-9.

6. McLay, C.D.A.; Ritchie, G.S.P.; Porter, W.M.; Cruse, A. Amelioration of subsurface acidity in sandy soils in low rainfall regions. 2. Changes to soil solution composition following the surface application of gypsum and lime. Aust. J. Soil Res. 1994, 32, 847-865. [CrossRef]

7. Zoca, S.M.; Penn, C. An important tool with no instruction manual: A review of gypsum use in agriculture. Adv. Agron. 2017, 144, 1-44. [CrossRef]

8. Sumner, M.E. Gypsum as an Ameliorant for the Subsoil Acidity Syndrome; Publication No 01-024-090; Florida Institute of Phosphate Research: Bartow, FL, USA, 1990.

9. Smith, C.J.; Peop1es, M.B.; Keerthisinghe, T.R.; James, T.R.; Garden, D.L.; Tuomi, S.S. Effect of surface applications of lime, gypsum and phosphogypsum on the alleviating of surface and subsurface acidity in a soil under pasture. Aust. J. Soil Res. 1994, 32, 995-1008. [CrossRef]

10. Alva, A.K.; Sumner, E.M.; Noble, A.D. Alleviation of aluminium toxicity by phospho-gypsum. Commun. Soil Sci. Plant Anal. 1988, 19, 385-403. [CrossRef]

11. Curtin, D.; Syers, J.K. Mechanism of sulphate adsorption by two tropical Soils. J. Soil Sci. 1990, 41, $295-304$. [CrossRef]

12. Blum, S.C.; Caires, E.F.; Alleoni, L.R.F. Lime and phosphogypsum application and sulfate retention in subtropical soils under no-till system. J. Soil Sci. Plant Nutr. 2013, 13, 279-300. [CrossRef]

13. Anderson, G.C. Sulfate sorption as measured by a buffering index over a range of soil properties from south Western Australia. Soil Res. 2020, 58, 651-661. [CrossRef]

14. Tiecher, T.; Pias, O.H.C.; Bayer, C.; Martins, A.P.; Denardin, L.G.O.; Anghinoni, I. Crop response to gypsum application to subtropical soils under no-till in Brazil: A systematic review. Rev. Bras. Cienc. Solo. 2018, 42, e0170025. [CrossRef]

15. Anderson, G.C.; Fillery, I.R.P.; Ripper, F.H.; Leach, B.J. Sulfur mineralization in a coarse-textured soil after different sulfate fertilization histories and yield responses of wheat and lupin. Aust. J. Soil Res. 2006, 44, 165-174. [CrossRef]

16. Wong, M.T.F.; Wittwer, K. Positive charge discovered across Western Australian wheatbelt soils challenges key soil and nitrogen management assumptions. Aust. J. Soil Res. 2009, 47, 127-135. [CrossRef]

17. Caires, E.F.; Joris, H.A.W.; Churka, S. Long-term effects of lime and gypsum additions on no-till corn and soybean yield and soil chemical properties in southern Brazil. Soil Use Manag. 2011, 27, 45-53. [CrossRef]

18. Zambrosi, F.C.B.; Alleoni, L.R.F.; Caires, E.F. Nutrient concentration in soil water extracts and soybean nutrition in response to lime and gypsum applications to an acid Oxisol under no-till system. Nutr. Cycl. Agroecosyst. 2007, 79, 169-179. [CrossRef]

19. Isbell, R.F.; National Committee on Soil and Terrain. The Australian Soil Classification, 2nd ed.; CSIRO Publishing: Collingwood, VIC, Australia, 2016.

20. Rayment, G.E.; Lyons, D.J. Soil Chemical Methods-Australasia; Aust. Soil and Land Survey Handbooks Series; CSIRO Publishing: Melbourne, Australia, 2010; ISBN 9780643101364. 
21. Blair, G.J.; Chinoim, N.; Lefroy, R.D.B.; Anderson, G.C.; Crocker, G.J. A soil sulfur test for pasture and crops. Aust. J. Soil Res. 1991, 29, 619-629. [CrossRef]

22. VSN International Genstat for Windows, 18th ed.; VSN International: Hemel Hempstead, UK, 2015; Available online: genstat.co.uk (accessed on 1 December 2020).

23. SYSTAT Sigmaplot 12.5; SYSTAT: San Jose, CA, USA, 2013; Available online: systatsoftware.com (accessed on 16 December 2020).

24. Anderson, G.C.; Pathan, S.; Hall, D.J.M.; Sharma, R.; Easton, J. Short and long term effects of lime and gypsum application on acid soils in a water-limited environment 3. Soil solution properties. 2020; unpublished; manuscript in preparation.

25. Johnson, D.W.; Mitchell, M.J. Responses of forest ecosystems to changing sulfur inputs. In Sulfur in the Environment; Maynard, D.G., Ed.; Marcel Dekker: New York, NY, USA, 1998; pp. 219-262.

26. Khanna, P.K.; Prenzel, J.; Meiwes, K.J.; Ulrich, B.; Matzner, E. Dynamics of sulfate retention by acid forest soils in an acidic deposition environment. Soil Sci. Soc. Am. J. 1987, 51, 446-452. [CrossRef]

27. Bolan, N.S.; Adriano, D.C.; Curtin, D. Soil acidification and liming interactions with nutrient and heavy metal transformation and bioavailability. Adv. Agron. 2003, 78, 215-272.

28. Aitken, R.L.; Dickson, T.; Moody, P.W. Field amelioration of acidic soils in south-east Queensland. II. Effect of amendments on the yield and leaf nutrient composition of maize. Aust. J. Agric. Res. 1998, 49, 639-647. [CrossRef]

29. Dolling, P.J.; Ritchie, G.S.P. Estimates of soil solution ionic strength and the determination of $\mathrm{pH}$ in West Australian soils. Aust. J. Soil Res. 1985, 23, 309-314. [CrossRef]

30. McLay, C.D.A.; Ritchie, G.S.P.; Porter, W.M.; Cruse, A. Amelioration of subsurface acidity in sandy soils in low rainfall regions. 1. Responses of wheat and lupins to surface-applied gypsum and lime. Aust. J. Soil Res. 1994, 32, 835-846. [CrossRef]

31. Upjohn, B.; Fenton, G.; Conyers, M. Soil Acidity and Liming. Agfact AC. 19, 3rd ed.; NSW Department of Primary Industries: Orange, NSW, Australia, 2005.

32. Li, G.D.; Conyers, M.K.; Helyar, K.R.; Lisle, C.J.; Poile, G.J.; Cullis, B.R. Long-term surface application of lime ameliorates subsurface soil acidity in the mixed farming zone of south-eastern Australia. Geoderma 2019, 338, 236-246. [CrossRef]

33. Stumm, W.; Morgan, J.J. Aquatic Chemistry: Chemical Equilibria and Rates in Natural Waters; John Wiley and Sons: New York, NY, USA, 1996; ISBN 978-0-471-51185-4.

34. Nye, P.H.; Ameloko, A.Y. Predicting the rate of dissolution of lime in soils. J. Soil Sci. 1987, 38, 641-644. [CrossRef]

35. Whitten, M.G.; Wong, M.T.F.; Rate, A.W. Amelioration of subsurface acidity in the south-west of Western Australia: Downward movement and mass balance of surface-incorporated lime after 2-15 years. Aust. J. Soil Res. 2000, 38, 711-728. [CrossRef]

36. Azam, G.; Gazey, C. Slow movement of alkali from surface-applied lime warrants the introduction of strategic tillage for rapid amelioration of subsurface acidity in south-western Australia. Soil Res. 2020. [CrossRef]

37. Menzies, N.W.; Bell, L.C.; Edwards, D.G. Exchange and solution phase chemistry of acid, highly weathered soils. I. Characteristics of soils and the effects of lime and gypsum amendments. Aust. J. Soil Res. 1994, 32, 251-267. [CrossRef]

38. Scanlan, C.A.; Brennan, R.F.; D'Antuono, M.F.; Sarre, G.A. The interaction between soil pH and phosphorus for wheat yield and the impact of lime-induced changes to soil aluminium and potassium. Soil Res. 2017, 55, 341-353. [CrossRef]

39. De Vargas, J.P.R.; Santos, D.R.; Bastos, M.C.; Schaefer, G.; Parisi, P.B. Application forms and types of soil acidity corrective: Changes in depth chemical attributes in long term period experiment. Soil Tillage Res. 2019, 185, 47-60. [CrossRef]

40. Costa, C.H.M.; Carmeis Filho, A.C.A.; Crusciol, C.A.C.; Soratto, R.P.; Guimarães, T.M. Intensive annual crop production and root development in a tropical acid soil under long-term no-till and soil-amendment management. Crop Pasture Sci. 2018, 69, 488-505. [CrossRef]

41. Caires, E.F.; Alleoni, L.R.F.; Cambri, M.A.; Barth, G. Surface application of lime for crop grain production under a no-till system. Agron. J. 2005, 97, 791-798. [CrossRef]

42. Costa, C.H.M.; Crusciol, C.A.C. Long-term effects of lime and phosphogypsum application on tropical no-till soybean-oat-sorghum rotation and soil chemical properties. Eur. J. Agron. 2016, 74, 119-132. [CrossRef] 
43. Crusciol, C.A.C.; Artigiani, A.C.C.A.; Arf, O.; Carmeis Filho, A.C.A.; Soratto, R.P.; Nascente, A.S.; Alvarez, R.C.F. Soil fertility, plant nutrition, and grain yield of upland rice affected by surface application of lime, silicate, and phosphogypsum in a tropical no-till system. Catena 2016, 137, 87-99. [CrossRef]

44. Fontoura, S.M.V.; de Castro Pias, O.H.; Tiecher, T.; Cherubin, M.R.; de Moraes, R.P.; Bayer, C. Effect of gypsum rates and lime with different reactivity on soil acidity and crop grain yields in a subtropical Oxisol under no-tillage. Soil Tillage Res. 2019, 193, 27-41. [CrossRef]

Publisher's Note: MDPI stays neutral with regard to jurisdictional claims in published maps and institutional affiliations.

(C) 2020 by the authors. Licensee MDPI, Basel, Switzerland. This article is an open access article distributed under the terms and conditions of the Creative Commons Attribution (CC BY) license (http://creativecommons.org/licenses/by/4.0/). 